\title{
The use of high hydrostatic pressure in the technology of whole muscle meat products
}

\author{
Irina Prokopenko, Nikolay Pokintelitsa, Yuri Velyaev", Dmitrij Eryomenko and Olga \\ Svetlichnaya \\ Sevastopol State University, 299053, Universitetskaya St., 33, Sevastopol, Russia
}

\begin{abstract}
The work examined the effect of high hydrostatic pressure on the chemical composition and microbiological indicators of poultry meat. Data on the mass fraction of moisture, fat, protein and ash before and after processing the product with high hydrostatic pressure are presented. Pressure treatment modes are justified, at which it is possible to obtain finished products. The formulation of a whole-muscle product from poultry meat has been developed, as well as a technological scheme for preparing a new product using innovative technology.
\end{abstract}

\section{Introduction}

In the preparation of meat products, raw materials are subjected to different types of heat treatment, as a result of which it is possible to destroy nutrients, the formation of toxic substances, which can lead to a deterioration in the quality of finished products, and negatively affect their environmental safety [1-5].

Modern research is devoted to the development of innovative approaches in the technology of meat products, aimed at resource saving, intensification of production processes and improvement of consumer properties of finished products. One such method is high hydrostatic pressure (HHP) technology [6-8].

In world practice, the HHP or the so-called "cold pasteurization" began to be used in the early 2000s. The United States Department of Agriculture (USDA) and the Food Safety and Control Service (FSIS) have chosen high-pressure processing as the safest way to preserve food [9-12].

In the last century, foreign scientists have done innovative work to study the possibility of using high pressure in food technologies. In 1929, Bridgman P.W. and Conand I.B. professors found that egg white and meat proteides clot under a pressure of 6,000 atmospheres at room temperature [13-16]. The results of these studies showed that pressure in a number of organic compounds causes irreversible reactions.

During the years 1980-1990 studies were continued on the effect of barotage treatment on biological materials [17-23], and it also became possible to use this method in food processing. This later application of pressure can be explained by the fact that special equipment is required to carry out various processes under compression conditions. Therefore, only with the development of the technology of durable metals and the methods

${ }^{*}$ Corresponding author: velyaevyo@yandex.ru 
for making appropriate equipment from them, it became possible to use the new technology, first for research purposes, and then in industry.

To date, it has been established that the use of the new technology allows controlling enzymatic processes, ensuring the inactivation of microorganisms [24], preventing the breakdown of vitamins and other nutrients. Hydrostatic pressure simultaneously affects the entire thickness of the product, as a result of which the duration of processing of the raw materials is reduced, energy and fuel resources are saved.

\section{Experimental}

The purpose of our research was to develop a technology for the production of an allmuscle product from poultry meat using high pressure. The subject of research was a chilled fillet of broiler chickens.

The following tasks were solved in the work to determine the chemical composition of meat, study its microbiological indicators, determine the modes of pasteurization of the HHP and develop the formulation and technology for the production of the finished product.

Studies were conducted according to standard methods $[25,26]$. The control sample was boiled fillet. The samples were packed in a shrink film under vacuum. HHP treatment was carried out at $200,300,400,500,600,700 \mathrm{MPa}$ for 30 minutes at $20^{\circ} \mathrm{C}$ in an automated high-pressure plant. Polyethylsiloxane fluid was used as the working fluid.

\section{Results and discussion}

A study of the total chemical composition of the control and prototypes made it possible to obtain data that characterize the nutritional value of meat raw materials, which is more dependent on the quantitative ratio of moisture, protein, fat and minerals.

Table 1. Total chemical composition of samples after treatment with high hydrostatic pressure.

\begin{tabular}{|c|c|c|c|c|c|}
\hline \multirow{2}{*}{$\begin{array}{c}\text { Sample } \\
\text { number }\end{array}$} & Pressure value, MPa & \multicolumn{4}{|c|}{ Mass content, \% } \\
\cline { 3 - 6 } & & moisture & animal fat & protein & ash \\
\hline 1 & control sample & $74,68 \pm 0,58$ & $2,38 \pm 0,26$ & $21,91 \pm 0,50$ & $1,03 \pm 0,42$ \\
\hline 2 & 200 & $74,66 \pm 0,41$ & $2,14 \pm 0,41$ & $22,18 \pm 0,58$ & $1,02 \pm 0,37$ \\
\hline 3 & 300 & $74,67 \pm 0,26$ & $2,33 \pm 0,33$ & $21,98 \pm 0,50$ & $1,02 \pm 0,33$ \\
\hline 4 & 400 & $74,66 \pm 0,42$ & $2,38 \pm 0,58$ & $21,92 \pm 0,26$ & $1,04 \pm 0,26$ \\
\hline 5 & 500 & $74,59 \pm 0,50$ & $2,03 \pm 0,26$ & $22,31 \pm 0,58$ & $1,07 \pm 0,37$ \\
\hline 6 & 600 & $74,55 \pm 0,33$ & $2,07 \pm 0,37$ & $22,30 \pm 0,42$ & $1,08 \pm 0,41$ \\
\hline 7 & 700 & $74,56 \pm 0,37$ & $2,03 \pm 0,33$ & $22,33 \pm 0,41$ & $1,08 \pm 0,50$ \\
\hline
\end{tabular}

The data obtained show that the content of basic food components in the test samples does not differ significantly from the control; therefore, treatment with high hydrostatic pressure of poultry meat does not affect the chemical composition of this raw material.

The degree of inactivation of microorganisms during barking depends on the amount of pressure and duration of action, the kind of bacteria, the temperature of the process, etc. We studied bacteriological indicators of meat processed at different parameters of HHP. To do this, the total insemination of meat (TIOM), the presence of bacteria of the coli group (Coliforms), pathogenic microorganisms (including bacteria of the Salmonella group), bacteria of the protea genus, as well as coagulase-positive staphylococci were determined. The samples were treated under the above conditions at $20 \pm 1{ }^{\circ} \mathrm{C}$. The results of the study are shown in Table 2. 
Table 2. Results of bacteriological analysis of samples.

\begin{tabular}{|c|c|c|c|c|c|c|}
\hline \multicolumn{2}{|c|}{ Sample } & \multicolumn{4}{|c|}{ Parameters } \\
\hline № & $\begin{array}{c}\text { Pressure } \\
\text { value, } \\
\text { MPa }\end{array}$ & $\begin{array}{c}\text { TIOM, } \\
\text { CFU in 1 g }\end{array}$ & $\begin{array}{c}\text { Coliform } \\
\text { bacteria in } \\
0,0001 \mathrm{~g}\end{array}$ & $\begin{array}{c}\text { Pathogenic } \\
\text { microorganisms, } \\
\text { including bacteria of } \\
\text { the genus Salmonella } \\
\text { in } 25 \mathrm{~g}\end{array}$ & $\begin{array}{c}\text { Sulfite } \\
\text { reducing } \\
\text { clostridia } \\
\text { in 0,01 g }\end{array}$ & $\begin{array}{c}\text { Bacteria of } \\
\text { the protea } \\
\text { genus } \\
\text { in 0,1 g }\end{array}$ \\
\hline 1 & $\begin{array}{c}\text { control } \\
\text { sample }\end{array}$ & $3,5 \cdot 10^{4}$ & $\begin{array}{c}\text { single } \\
\text { colonies }\end{array}$ & unselected & unselected & unselected \\
\hline 2 & 200 & $2,8 \cdot 10^{4}$ & $\begin{array}{c}\text { single } \\
\text { colonies }\end{array}$ & unselected & unselected & unselected \\
\hline 3 & 300 & $1,5 \cdot 10^{3}$ & unselected & unselected & unselected & unselected \\
\hline 4 & 400 & $1,0 \cdot 10^{3}$ & unselected & unselected & unselected & unselected \\
\hline 5 & 500 & $\begin{array}{c}\text { less than } \\
1,5 \cdot 10\end{array}$ & unselected & unselected & unselected & unselected \\
\hline 6 & 600 & $\begin{array}{c}\text { less than } \\
1,5 \cdot 10\end{array}$ & unselected & unselected & unselected & unselected \\
\hline 7 & 700 & $\begin{array}{c}\text { less than } \\
1,5 \cdot 10\end{array}$ & unselected & unselected & unselected & unselected \\
\hline
\end{tabular}

The culinary readiness of meat products is determined by the inactivation of the enzyme and the indicator of the residual activity of acid phosphatase. We conducted a study to establish the possibility of using high-pressure processing of poultry meat instead of traditional heat treatment. The results of the study are presented in table 3.

Table 3. The amount of acid phosphatase in the samples.

\begin{tabular}{|c|c|c|}
\hline $\begin{array}{c}\text { Sample } \\
\text { number }\end{array}$ & Pressure value, MPa & $\begin{array}{c}\text { Mass content of } \\
\text { phenol, \% }\end{array}$ \\
\hline & standard value & not more than 0,006 \\
\hline 1 & control sample & $0,0055 \pm 0,00039$ \\
\hline 2 & 200 & $0,0069 \pm 0,00041$ \\
\hline 3 & 300 & $0,0068 \pm 0,00037$ \\
\hline 4 & 400 & $0,0067 \pm 0,00042$ \\
\hline 5 & 500 & $0,0066 \pm 0,00044$ \\
\hline 6 & 600 & $0,0059 \pm 0,00034$ \\
\hline 7 & 700 & $0,0056 \pm 0,00047$ \\
\hline
\end{tabular}

The findings indicate that high-pressure treatment inactivates the thermolabile enzyme. A comparative evaluation of the results of the study indicates that with an increase in the hydrostatic pressure, a decrease in the residual amount of acidic phosphatase occurs and a threshold value $(6 \mathrm{mg}$ phenol per $100 \mathrm{~g}$ ) is achieved when treated at $600 \mathrm{MPa}$.

The obtained data indicate that the most rational regime for the production of whole muscle products from poultry meat is pressure treatment at $700 \mathrm{MPa}$ for 30 minutes at 20 ${ }^{\circ} \mathrm{C}$.

The figure 1 shows the appearance of meat processed at the specified parameters.

We noted that the sample, processed at $700 \mathrm{MPa}$ in color, smell and appearance, resembled boiled poultry meat, but it had a more tender and juicy consistency. 


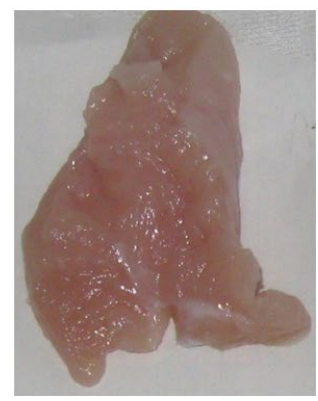

a

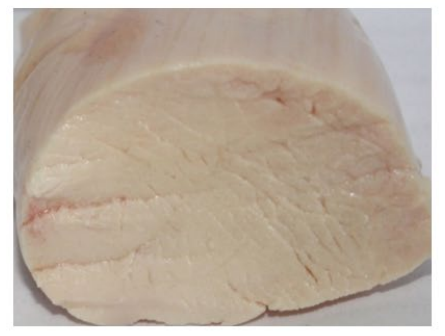

e

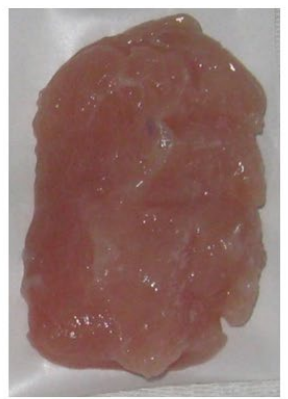

b

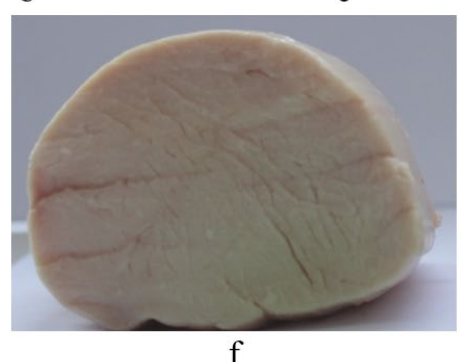

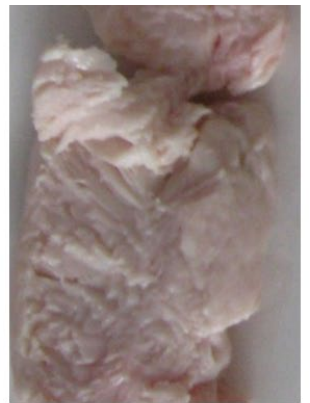

d

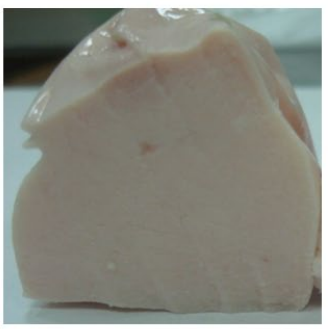

g

Fig. 1. The appearance of meat after pressure treatment, MPa: a - control sample, b-200, c - 300, d $-400, \mathrm{e}-500, \mathrm{f}-600, \mathrm{~g}-700$.

Chilled poultry meat and natural ingredients were used to produce the finished products. We offer the formula of whole-muscle meat product: Chicken meat, broiler chickens - 100 $\mathrm{kg}$, culinary food salt - $2500 \mathrm{~g}$, sugar sand - $300 \mathrm{~g}$, ground black pepper - $100 \mathrm{~g}$, ground allspice - $45 \mathrm{~g}$, nutmeg - $60 \mathrm{~g}$, garlic - $200 \mathrm{~g}$. Polymer films for vacuum packaging were used as the shell.

The process scheme of the finished product production consists of the following operations (fig. 2): the meat obtained after cutting (1) is syringed with brine in an amount of $10-15 \%$ of the raw material (2) weight and mixed with spices, and then the meat pieces are packed under vacuum (3). Then raw material is sent to high-pressure plant and hydrostatic treatment is carried out at $700 \mathrm{MPa}$, duration is $30 \mathrm{~min}$, temperature is $20 \pm 2{ }^{\circ} \mathrm{C} \mathrm{(4).}$ Finished products are sent for labeling, packaging (5), storage (6) under standard conditions and implementation.

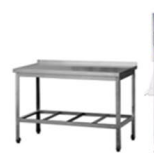

1

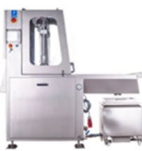

2

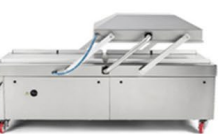

3

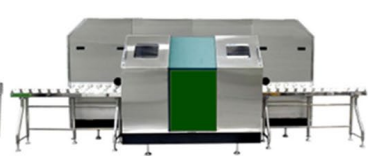

4

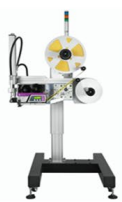

5

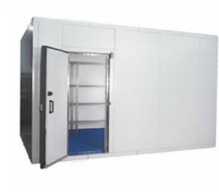

6

Fig. 2. Instrumentation and technological scheme for the production of whole-muscle product: 1 table for handling carcasses, 2 - injector, 3 - vacuum packaging machine, 4 - high-pressure apparatus, 5 - label applicator printer; 6 - storage chamber.

\section{Conclusions}

In the course of studies, it was found that high pressure treatment does not lead to changes in the chemical composition of meat, but contributes to the inactivation of microorganisms and thermolabile enzyme when treated above $600 \mathrm{MPa}$ for 30 minutes at room temperature. 
Presented formula of whole-muscle product from poultry meat contains only natural ingredients, which can be used in dietary nutrition of population.

The advantages of the innovative technology of producing the finished product compared to the thermal method include the following: a reduction in the number of technological operations; reduction of process equipment; reduction of the ready product production time by 3-5 times; reduction of production space; a reduction in the labour force. Thus, HHP technology is safe and resource-efficient.

\section{References}

1. S. Kakde, R.S. Bhopal, S. Bhardwaj, A. Misra, Nutrition, 33, 216-224 (2017)

2. R.M. Aadil, U. Roobab, A.A. Maan, G.M. Madni, Encyclopedia of Food Chemistry, 70-75 (2019).

3. Y. Cui, X. Shi, Y. Tang, Y. Xie, Z. Dua, Food Chemistry, 313, 125930 (2020).

4. K. Skog, A. Solyakov, P. Arvidsson, M. Jägerstad, Screening for toxic Maillard reaction products in meat flavours and bouillons, The Maillard Reaction in Foods and Medicine, 444 (2005)

5. F. Shahidi, A.G.P. Samaranayaka, R.B. Pegg, Heat effects on meat: Maillard reaction and browning, Encyclopedia of Meat Sciences, 578-592 (2004).

6. H.-W. Huang, C.-P. Hsu, C.-Y. Wang, Journal of Food and Drug Analysis, 28, 1, 1-13, (2020)

7. O.P. Soladoye, Z. Pietrasik, Utilizing high pressure processing for extended shelf life meat products, Reference Module in Food Science (2018)

8. S. Xue, C. Wang, Y.H. Brad Kim, G. Bian, M. Han, X. Xu, G. Zhou, Food Chemistry, 306, 125602 (2020)

9. Z.S. Seregely, I. Dalmadi, J. Farkas, High Pressure Research: An International Journal, 27 (1), 23-26 (2007).

10. I.C. Duru, M. Andreevskaya, P. Laine, T.M. Rode, A. Ylinen, T. Lovdal, N. Bar, P. Crauwels, C.U. Riedel, F.I. Bucur, A.I. Nicolau, P. Auvinen, BMC Genomics, 21 (455) (2020).

11. E. De Angelis, S.L. Bavaro, G. Forte, R. Pilolli, L. Monaci, Nutrients, 10, 1679 (2018)

12. A.Yu. Volkov, N.A. Kruglikov, A.V. Alexandrov, V.V. Kotkova, IOP Conf. Series: Materials Science and Engineering, 1008, 012012 (2020)

13. P.W. Bridgman, R.B. Dow, Journal of chemical physics, 3, 35-41 (1935)

14. P.W. Bridgman, Physicai review, 48, 825-847 (1935)

15. P.W. Bridgman 18, 1, 1-93 (1948)

16. P.W. Bridgman, Rheological properties at high pressure, 21, 7-16 (1946)

17. J.C. Cheftel, J. Culioli, Meat Science, 46, 3, 211-236 (1997)

18. D. Knorr Hydrostatic pressure treatment of food: microbiology, New Methods of Food Preservation, 159-175 (1995)

19. A. Toth, C. Nemeth, I. Zeke, A. Barkoi, K. Hidas, L. Friedrich, Progress in Agricultural Engineering Sciences, 16, S1, 67-74 (2020)

20. F. Witte, S. Smetana, V. Heinz, N. Terjung, Meat Science, 170, 108241 (2020).

21. G. Joseph, K.R. Remya Kumari, C.K. Kamalakanth, J. Bindu, K.K Asha, Journal of Aquatic Food Product Technology, 29 (6), 531-543 (2020) 
22. K. Kantono, N. Hamid, I. Oey, Y.C. Wu, Q. Ma, M. Farouk, D. Chadha, Foods, 9, 1444 (2020)

23. Md.H. Rahman,T.-H. Mu, M. Zhang, M.-M. Ma, H.-N. Sun, Journal of Food Process Preservation, 00, e14852 (2020)

24. A. Okamoto, A.Suzuki, Progress in Biotechnology, 19, 571-576 (2002)

25. A.T. Richards, Encyclopedia of Analytical Science (Third Edition), 436-450 (2019)

26. F. Toldra, M. Flores, M.C. Aristoy, Encyclopedia of Meat Sciences (Second Edition), 206-211 (2014) 